\title{
Engineering geologic assessment of the slope movements and liquefaction failures of the 23 October 2011 Van earthquake $\left(M_{\mathrm{w}}=7.2\right)$
}

\author{
A. Karakaş, Ö. Coruk, and B. Doğan \\ Kocaeli University, Engineering Faculty, Department of Geological Engineering, İzmit, Kocaeli, Turkey \\ Correspondence to: A. Karakaş (akarakas@kocaeli.edu.tr) \\ Received: 30 October 2012 - Published in Nat. Hazards Earth Syst. Sci. Discuss.: - \\ Revised: 29 January 2013 - Accepted: 18 April 2013 - Published: 26 April 2013
}

\begin{abstract}
On 23 October 2011, a $M_{\mathrm{w}}=7.2$ earthquake occurred in the Van Province in eastern Turkey, killing 604 people. The earthquake was triggered by a thrust fault due to a compression stress in the region, and caused extensive damage over a large area. Many structures in the earthquake region collapsed, and the damage spread from the city of Van to the town of Erciş, in a distance of $60 \mathrm{~km}$. The earthquake generated several slope movements and liquefaction failures in the region, and this study evaluates these processes from the perspective of engineering geology, and presents field and laboratory results related to these processes. Attenuation relationships were used for estimation of peak ground accelerations (PGAs), and an empirical liquefaction evaluation method employing ground accelerations was used to define threshold accelerations initiating the liquefaction.

The results demonstrate that landslides were widespread and more frequently observed in the field in comparison with earthflows and rockfalls. Flow-type liquefaction and lateral spreading was found to be widespread and more common than the liquefaction-related settlement. The minimum threshold acceleration value for the initiation of soil liquefaction was calculated to be $188.87 \mathrm{~cm} \mathrm{~s}^{-2}(\sim 0.19 \mathrm{~g})$ in the earthquake region. Laboratory results indicated that the soil liquefaction was closely associated with grain size. The slope instabilities, liquefaction and associated ground failures occurred mainly in rural areas, and their impact on structures was quite low as compared to the human loss and structural damage by the earthquake.
\end{abstract}

\section{Introduction}

Earthquakes are natural events that have different effects on the earth. Some effects severely affect humans, man-made structures, and nature. The severity of the impact is directly related to the magnitude of the earthquake, the local geological conditions, and the structural quality of the buildings. A large magnitude earthquake could have a disastrous impact over a large area.

The Van earthquake, which occurred in East Anatolia, Turkey (Fig. 1), on 23 October 2011, severely affected humans, man-made structures and nature. The total human casualty was 604 . The structural damage included mainly buildings with 4-8 stories in the town of Erciş and Van city center, adobe houses in villages, main highways, factories, and historical monuments. In addition to the human losses and the structural damage, the area suffered several slope failures as well as extensive liquefaction and related failures in different locations of the Van region during the field campaign. The damage caused by the slope failures and liquefaction was minor compared to the human loss and destructive structural damage. In contrast, several large earthquakes worldwide have generated large mass movements and ground deformations related to liquefaction in the past. Among these earthquakes, the 1964 Alaskan earthquake $\left(M_{\mathrm{w}}=9.2\right)$ generated extensive liquefaction and numerous landslides, which caused major damage to structures. The 1989 Loma Prieta earthquake $\left(M_{\mathrm{w}}=6.9\right)$ triggered a great number of landslides leading to severe damage to structures and the blocking of major highways. The 1995 Kobe earthquake $\left(M_{\mathrm{w}}=6.9\right)$ caused extensive liquefaction, resulting in sand boils, lateral spreading, and settlement-type ground deformations. 


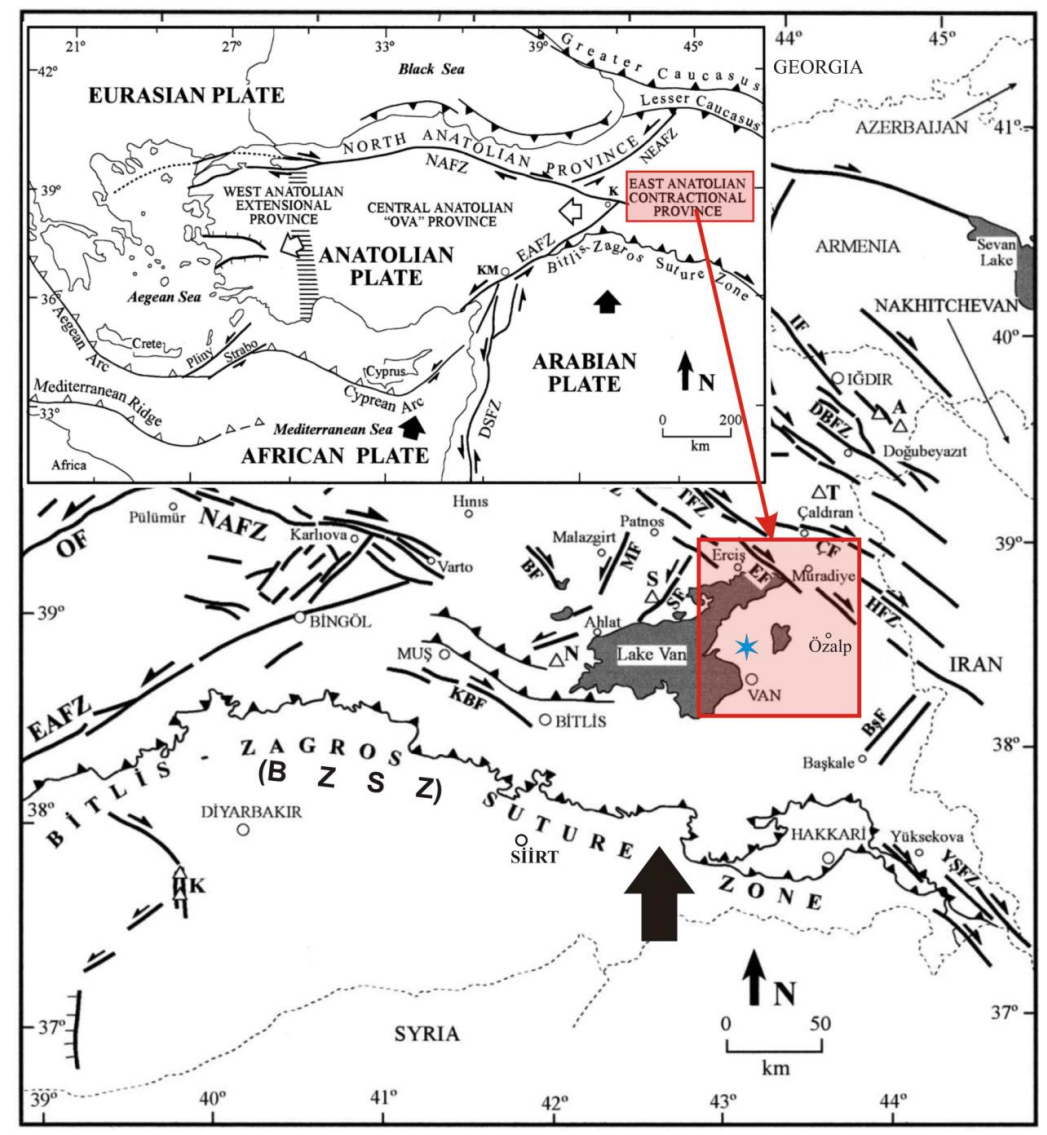

Fig. 1. Location map of the study area and simplified active tectonic lines and regions in Turkey. General view of active faults in Van and surrounding areas along with direction of compressional stress creating the compression area in East Anatolia. The 23 October 2011 Van earthquake region is shown in a red squared area with the earthquake epicenter (blue star). A - Mount Ararat, T - Mount Tendürek, S Mount Süphan, N - Mount Nemrut, NAFZ - North Anatolian Fault Zone, IF - Iğdır Fault, DBFZ - Doğubeyazıt Fault Zone, TFZ - Tutak Fault Zone, HFZ - Hasan Timur Fault Zone, ÇF - Çaldıran Fault, SF - Süphan Fault, MF - Malazgirt Fault, BF - Bulanık Fault, EAFZ East Anatolian Fault Zone, YSFZ - Yüksekova-Şemdinli Fault Zone, EF - Erciş Fault, KBF - Kavakbası Fault, BşF - Başkale Fault, OF Ovacık Fault (compiled from Şengör et al., 1985; Barka, 1992; Şaroğlu et al., 1992; Bozkurt, 2001; Koçyiğit, 2002).

The 1999 İzmit (Gölcük) earthquake $\left(M_{\mathrm{w}}=7.4\right)$ also generated landslides and liquefaction-related surface features. The 2011 Christchurch earthquake $\left(M_{\mathrm{w}}=6.3\right)$ triggered several landslides, rockfalls and liquefaction, which caused loss of life and extensive damage to properties, roads, and other infrastructure.

There is a broad range of studies about earthquakes and their effects with regard to slope failures, liquefactions and related ground failures. A chronological summary of the work that concerns earthquake-triggered slope and liquefaction failures is as follows: JSCE (2000); Alberto and Romeo (2000); Wasowski and Gaudio (2000); Rajendran et al. (2001); Wang et al. (2003); Keefer et al. (2006); Kausar et al. (2010); Chigira et al. (2010); Miyagi et al. (2011); and GEER (2011).

The purpose of this study is to evaluate slope failures, liquefaction, and associated ground failures triggered by the 23 October 2011 Van earthquake from an engineering geology perspective. For this purpose, this study presents and discusses the occurrence of slope failure, liquefaction, and associated ground failures according to field observations in the Van earthquake region, and associates the slope and liquefaction failures to local geology. Attenuation relationships were used for estimation of peak ground accelerations (PGAs), and an empirical liquefaction evaluation method employing ground accelerations was used for defining threshold accelerations initiating the liquefaction. Additionally, 12 soil samples were taken from different localities of the earthquake region to define the relationship among liquefaction, grain size and soil type. The distribution, extent, and effects of the slope instabilities and liquefaction failures are also presented. GIS was used to map and display the spatial occurrences of geological impacts for the engineering geologic evaluation in the meizoseismal area of the earthquake.

The slope movements observed in the field reconnaissance were mainly landslides, earthflows, and rockfalls, 
while liquefaction features were flow-type liquefaction, lateral spreading and liquefaction-related ground settlements. Laboratory analysis of the soil samples indicates that the liquefied soils were mainly composed of fine- to medium-sand grains and that soil liquefaction is closely associated with the grain size. Engineering geological assessment of slope instabilities and liquefaction-related surface features is the basis of planning in development and engineering projects.

\section{Geological and tectonic setting}

The Van earthquake occurred in the Lake Van basin located in the East Anatolian region of Turkey, located approximately $60 \mathrm{~km}$ north of Bitlis-Zagros suture zone (BZSZ), constituting a collision boundary between the Arabian plate in the south and the Eurasian plate in the north (Fig. 1). The basement of the basin is comprised of ophiolitic rocks and metamorphic rocks of the Bitlis Massif (Şengör and Yllmaz, 1981; Hempton, 1987; Parlak et al., 2000). Two different sedimentary groups including rocks and deposits overlie the basement rocks (Güner, 1984; Yılmaz, 1990; Acarlar et al., 1991; Aydar et al., 2003). These sedimentary groups located in the basin consist of the Oligo-Miocene bottom group and the Plio-Quaternary upper group (Ketin, 1948; Şaroğlu and Y1lmaz, 1986; Yilmaz et al., 1981, 1993). The bottom group rocks, deposited in both marine and lacustrine environments, are composed of conglomerate, sandstone, mudstone, claystone, marl, and limestone (Aksoy, 1988; Sağlam, 2003). The upper group consists of a limestone-sandstoneconglomerate sequence deposited in lacustrine and fluvial environments, and unpacked gravel, sand, silt and clay intercalations (Özkaymak, 2003). Volcanic rocks of varying age, from $11 \mathrm{Ma}$ to 17 century $\mathrm{AD}$, cut through the other units (Şengör et al., 2008) (Fig. 2).

As a result of the closure of the Neo-Tethys Ocean due to subduction to the north, the BZSZ now constitutes the boundary between the Arabian and Eurasian plates. This zone turned into a collision zone surrounded by the north-dipping thrust faults at the beginning of the early Miocene (Şengör et al., 2008). Active contractional tectonics especially caused the crust to thicken in the region, and extends approximately $100 \mathrm{~km}$ north of the BZSZ including the Lake Van basin (Dewey and Burke, 1973; Şengör and Yılmaz, 1981). Concurrently, this compressional tectonic regime contributed to the development of intra-continental strike-slip faults and especially transtensional normal faults in the region (Şengör et al., 1985). The compressional tectonism dominated the region from Late Cretaceous to Paleocene and developed the Lake Van basin as a ramp-type basin during the Paleoceneupper Miocene. The pure compressional tectonism affecting Van and its vicinity continued its activities during the PlioQuaternary period and developed both strike-slip faults and normal faults in the geologic units deposited in the region (Şengör et al., 1985; Şengör and Kidd, 1979; Toker, 2006).

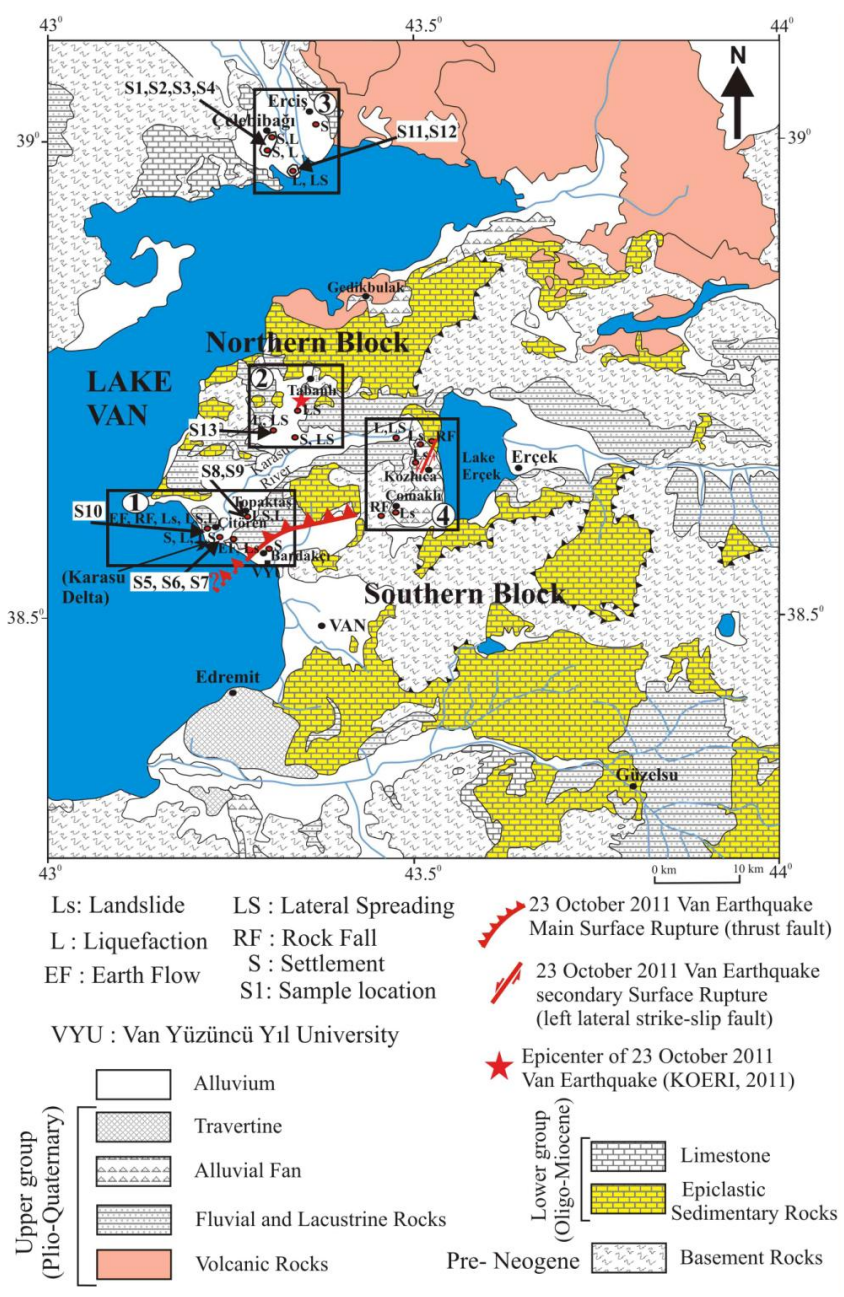

Fig. 2. Geology map of the Van region (MRE, 2002) and geographical distribution of mass movements and liquefaction features along with the main and secondary surface ruptures that occurred during the 23 October 2011 Van earthquake.

\section{Geomorphology of the Van region}

The Van Lake basin is located in the East Anatolia high plateau region. The East Anatolian continental lithosphere, thickened by the collision of a continental-continental along the Bitlis-Zagros suture zone, consists of high mountain ranges (approximately $53 \%$ of the region) and the plains between the mountains (Köse et al., 2005). Lake Van is bordered on the south by a high mountain range, while the east of Lake Van is comprised of plateau morphology. The morphology to the west of Lake Van contains volcanic cones. The highest point in the region is Mount Erek, with an elevation of $3204 \mathrm{~m}$. The mountain slopes are commonly steep. All of the rivers discharging into Lake Van suggest that the Lake Van basin is a closed basin. There are two lakes in the Lake Van basin: Lake Van in the west and Lake Erçek in the east. The deepest point of Lake Van is about $400 \mathrm{~m}$. 
The morphology of the investigation area presents a rugged topography with high elevations $(\sim 1650-2500 \mathrm{~m})$. Basins and shores of Lake Van constitute the flat areas in the region. The area of study had four different sites of slope instabilities and liquefaction failure occurrences (Fig. 2). When we look at the morphology of each site, the first site presents a flat area (average $1650 \mathrm{~m}$ ) surrounded by hills (average $1700 \mathrm{~m}$ ) in a NE-SW direction; the second site also contains a flat area (average $1710 \mathrm{~m}$ ) between ridges (average $1760 \mathrm{~m}$ ) in an E-W direction; the third site constitutes a flat area with an average $1660 \mathrm{~m}$ elevation. The fourth site, which is the highest of the area studied, presents a mountainous topography with elevations ranging between 1810 and $2522 \mathrm{~m}$ (Fig. 3). The morphology of the region was formed during the active tectonic period (approximately $20 \mathrm{Ma}$ ).

Continental climate conditions prevailed in the Van region. The precipitation regime in the region varies between levels typical of the Mediterranean and continental precipitation regimes. Most of the annual precipitation falls in the spring (39\%), followed by winter (26.6\%) and autumns $(27.2 \%)$. The least precipitation falls in summer $(7.1 \%)$ (TSMS, 2013). The slope and liquefaction failures are closely related to the geomorphological setting and climatic conditions.

\section{The 23 October 2011 Van earthquake}

An earthquake with $M_{\mathrm{w}}=7.2$ (KOERI, 2011) struck the Van Province located in the East Anatolia region of Turkey, on 23 October 2011. The earthquake was felt over a large area in the East Anatolia provinces. Although there are differences in the determined locations of the earthquake epicenters that are reported by different seismological networks, the epicenter located approximately $30 \mathrm{~km}$ north (Tabanll village) of Van city center according to the calculation of KOERI (2011) was adopted for this study (see Fig. 2). Settlements close to the epicenter experienced major damage. The town of Erciş is located approximately $30 \mathrm{~km}$ north of the epicenter and suffered the greatest damage and human loss due to its geologic settlement and building quality. The reported depth of the hypocenter varies from $5 \mathrm{~km}$ to $20 \mathrm{~km}$, and the fault mechanism solutions indicate a thrust dip slip fault with a minor left lateral strike-slip component (Irmak et al., 2012). The 23 October 2011 Van earthquake was caused by a N 70 Estriking and north-dipping main thrust fault that has the same dip direction (synthetic) as the BZSZ. The lengths of the fault plane and surface rupture are approximately $60 \mathrm{~km}$ and $8 \mathrm{~km}$ respectively. The observed maximum thrust offset is $0.15 \mathrm{~m}$, and the maximum left lateral offset is $0.09 \mathrm{~m}$ on the surface rupture (Irmak et al., 2012). Doğan and Karakaş (2013) indicated that the earthquake was generated by a blind thrust fault due to the shorter length from the main surface rupture to the sub-surface rupture. The earthquake created tectonic deformations, mass movements and lateral spreading with different geometries in an area measuring $50 \times 30 \mathrm{~km}^{2}$.

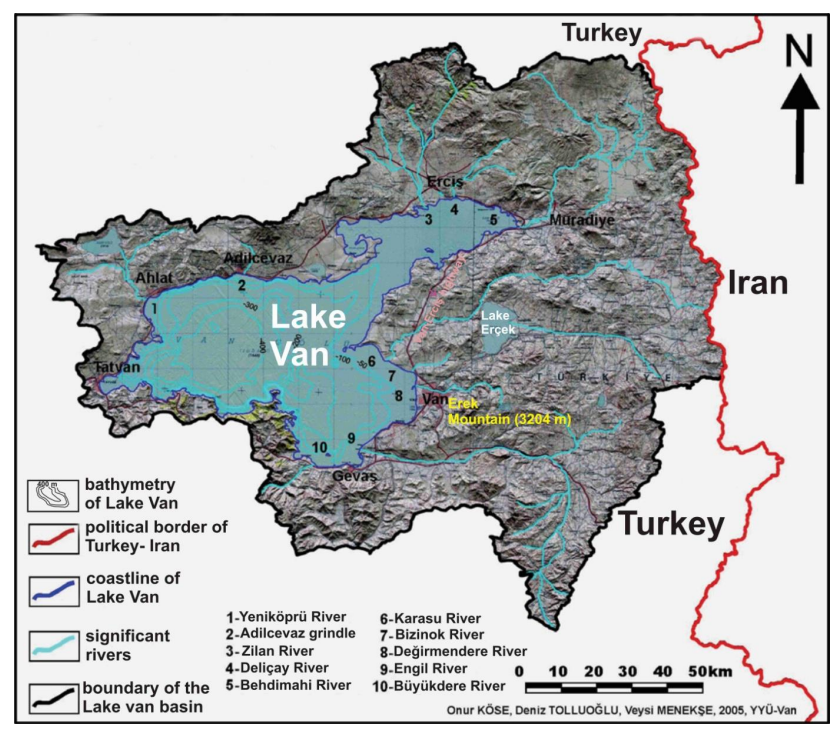

Fig. 3. The 3-D morphologic view of the Van region (Köse et al., 2005).

The major energy release of the earthquake lasted approximately $50 \mathrm{~s}$ (KOERI, 2011), and an intensity of IX was measured near the epicenter (Modified Mercalli Intensity Scale USGS, 2011). The aftershock sequence was intense for three months, and almost 3000 shocks with $M=2-6$ have been reported.

The earthquake was generated by the north-south compression of two continental blocks. The northern block (hanging wall) of the thrust fault moved towards the southern block so the impact of the earthquake was mainly concentrated on the northern block. The fault that generated the earthquake had not been previously marked on any active tectonic maps. Since the earthquake, the fault has been mapped, based on the surface rupture data gathered in the field, and reported in several preliminary Van earthquake reports (Akyüz et al., 2011; CGE, 2011; Doğan et al., 2011; Emre et al., 2011; METU-EERC, 2011; YTU-NSRC, 2011). Çetin et al. (2011) prepared a report summarizing the preliminary findings of field investigation studies performed after the Van earthquake. Also, a detailed structural damage evaluation can be found in the Van special earthquake report of EERI (2012).

\section{Attenuation relationships for estimation of PGAs}

It is believed that the site conditions due to geological setting play an important role in the damage distribution. Soft soils increase the ground shaking, and other factors such as liquefaction, ground failure, and structural deficiencies may also lead to heavy damage (Ulutaş et al., 2011). One of the earthquake hazard assessments related to ground shaking is typically done by means of an earthquake ground motion 
attenuation relationship, which provides the estimation of ground motion for an earthquake of a given magnitude at a different distance through a curve fitted to observed data (Ulutaş and Özer, 2010). Although the hazard assessment is not a simple function of magnitude and distance alone, it is used because the most common information available immediately following a damaging earthquake is its magnitude and epicenter

As a result of the increased number of stations and the database of strong ground motion after the 1999 İzmit (Gölcük) $\left(M_{\mathrm{w}}=7.4\right)$ and Düzce $\left(M_{\mathrm{w}}=7.2\right)$ earthquakes, new specific attenuation relationships have been developed for peak ground accelerations (PGAs) and spectral accelerations (SAs) in Turkey (Gülkan and Kalkan, 2002; Özbey et al., 2004; Ulusay et al., 2004; Akyol and Karagöz 2009; Ulutaş and Özer, 2010; Ulutaş et al., 2011). Most of the data employed in these relationships were from the Kocaeli and Düzce earthquakes of 1999. Özbey et al. (2004) used a model with two sources of random variation obtained from strong motion stations operating in northwestern Turkey and resulted from events that include the Kocaeli $\left(M_{\mathrm{w}}=7.4\right)$ and Düzce $\left(M_{\mathrm{w}}=7.2\right)$ earthquakes and their aftershocks. However, Ulusay et al. (2004) derived an attenuation equation for PGA based on a larger database that covers earthquakes that occurred in Turkey from 1995 to 2003 to develop domestic equations by using ground motion data obtained from the earthquakes. Ulusay et al. (2004) used the moment magnitude, distance to epicenter, site class coefficient indicators and largest horizontal PGA parameters in the attenuation relationship model. Ambraseys et al. (2005) also used a number of records from the NW of Turkey, where the relationship parameters are moment magnitude, distance to the surface projection of the fault, site class coefficient indicators, and faulting mechanism indicators. However, their relationships were derived by a weighted regression analysis, used to remove observed magnitude-dependent variance, on a set of 595 strong-motion records recorded in Europe and the Middle East.

No record of ground acceleration is available in the near field of the Van earthquake, although the strong ground motion was recorded by the stations located in the neighboring provinces. The distances between the strong ground stations recording the ground accelerations and the epicenter varied from $42 \mathrm{~km}$ to $590 \mathrm{~km}$. The Muradiye station, located approximately $42 \mathrm{~km}$ NE of the epicenter, was the closest station and recorded the highest PGA of $178.5 \mathrm{~cm} \mathrm{~s}^{-2}(0.182 \mathrm{~g})$ in the $\mathrm{N}-\mathrm{S}$ direction. The other stations recorded acceleration values between $0.1 \mathrm{~g}$ and $0.001 \mathrm{~g}$ within $95-590 \mathrm{~km}$ of the epicenter (DEMP-ED, 2011). A comparison of the PGAs recorded at the Muradiye, Bitlis, Muş, Malazgirt and Siirt stations with the attenuation relationships is shown in Fig. 4. These stations are within approximately 42 (Muradiye) to 158 (Siirt) kilometers of the epicenter.

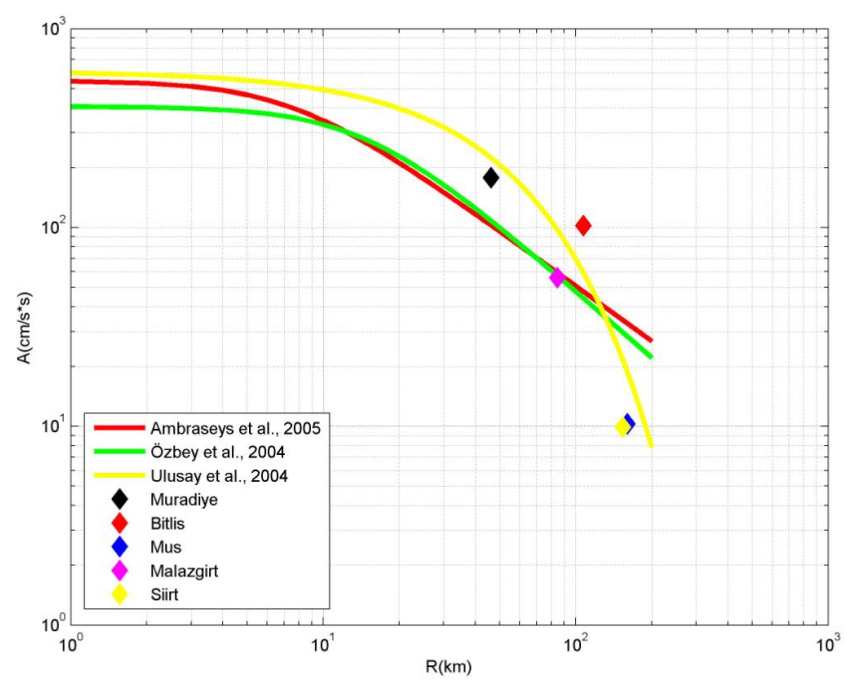

Fig. 4. Comparison of recorded strong ground motions with ground motion prediction equations.

\section{Engineering geology}

Rock masses and soil layers presented different behaviors according to their engineering geological properties both during and after (with the $4 \leq M \leq 5.5$ aftershocks) the 23 October 2011 Van earthquake, in the form of slope and ground failures. Slope movements developed on sound rocks presenting non-homogenous lithological variations and on weakly cemented rocks and fan deposits. Ground failures were mainly observed in non-cohesive, loose, mid-dense alluvial deposits as liquefaction and related failures.

\subsection{Slope instabilities}

Mass movements are downslope movements of earth material caused by gravity (Varnes, 1978). In some cases, earthquakes can trigger slope instabilities, and this is what occurred throughout the region on 23 October 2011 during the Van earthquake. Keefer (1984) provided a detailed study about slope failures caused by 40 earthquakes around the globe. Mass movements took place as slope failures, which were observed in the field to occur with different types of movement and materials. The earthquake occurred during a relatively wet season so the saturated slopes must have experienced an increase in pore water pressures due to the earthquake load.

The observed slope instabilities were mainly landslides, earthflows, and rockfalls. Landslide and earthflow type movements took place on slopes covered with predominantly fine-grained material. Rockfalls occurred on slopes composed of basement metamorphic rocks and other nonhomogenous sedimentary rocks. Slope instabilities occurred at high elevations ranging from $1650 \mathrm{~m}$ to $2500 \mathrm{~m}$ in the earthquake region. The occurrence of the landslides, 




Fig. 5. A view from a landslide on a slope located west of Lake Erçek.

earthflows, and rockfalls was widespread throughout the earthquake region (see Fig. 2). Landslides were observed on the slopes located close to the eastern shores of Lake Van and north and south of Kozluca, located to the east of Lake Erçek and to the south of Tabanlı village. Some landslides were fully developed (Fig. 5) while some were confined landslides that had a scrap but no visible surface ruptures in the foot of the displaced mass (TRB, 1996) (Fig. 6). The majority of the landslides were classified as shallow because the displaced material thickness was measured to be less than $5 \mathrm{~m}$. However, one or two landslides were deep, with a displaced material thickness between $5 \mathrm{~m}$ and $20 \mathrm{~m}$ (Zaruba and Mencl, 1982). The largest landslide encountered in the field covered an area of approximately $20000 \mathrm{~m}^{2}$ with $100 \mathrm{~m}$ width and $200 \mathrm{~m}$ length (Fig. 7). The volume of sliding material for this landslide was calculated to be approximately $40000 \mathrm{~m}^{3}$. Earthflows were limited and these were observed in the slopes located close to the eastern shores of Lake Van around Çitören (Fig. 8). Rockfalls were observed less frequently, but were recorded in the slopes near the eastern shores of Lake Van around Çitören (Fig. 9a), from a hill located in the southwest of Kozluca with the basement metamorphic rocks and on the slopes close to the western shores of Lake Erçek (Fig. 9b). In general the data demonstrate that landslides occurred more often than rockfalls and earthflows in the region.

\subsection{Liquefaction failures}

Soil liquefaction occurs in saturated cohesionless soils when exposed to strong shaking during earthquakes. The 23 October 2011 Van earthquake caused extensive liquefaction and related ground failures. Increase in pore water pressures in non-cohesive, loose and saturated alluvial soils due to earthquake strong ground motion enabled development of



Fig. 6. A view from a confined landslide on a slope located northwest of Kozluca village.

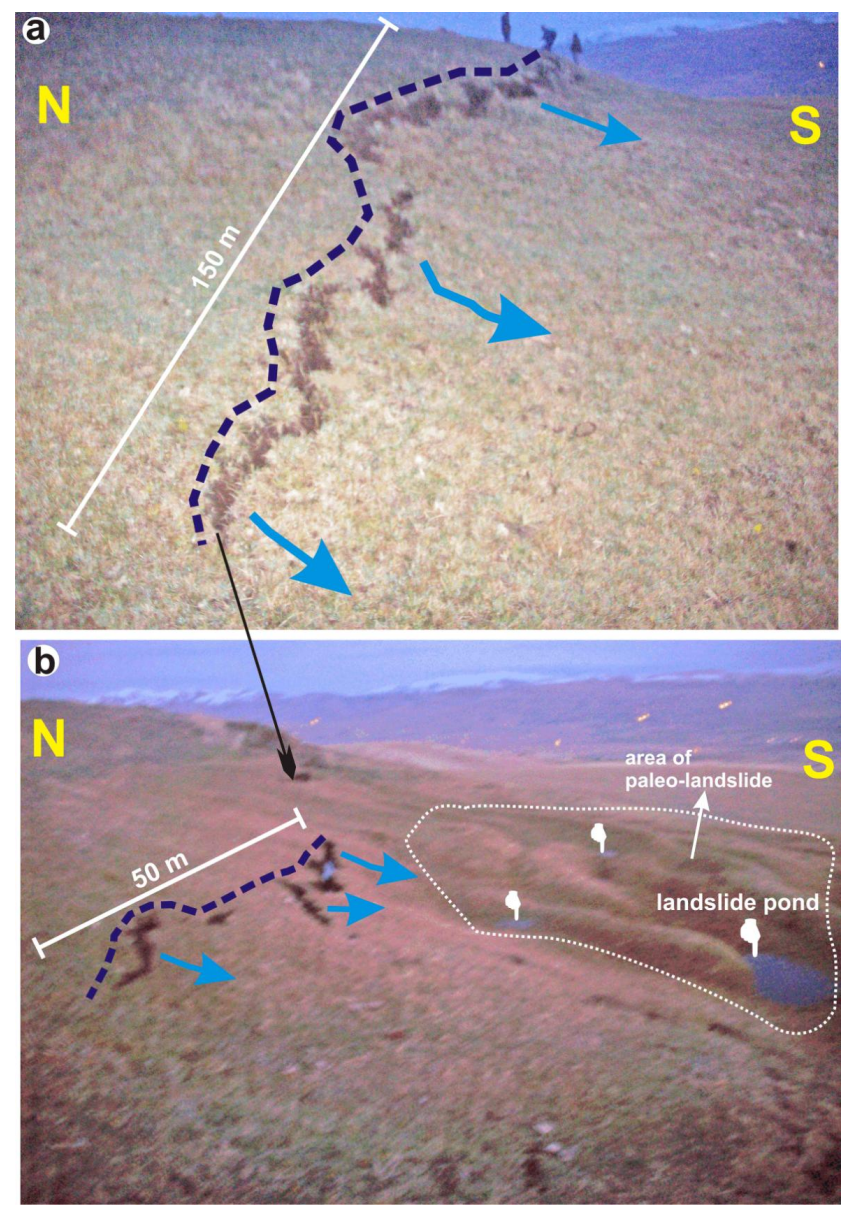

Fig. 7. The largest landslide with a $60 \mathrm{~cm}$ maximum scarp observed in the south of Çomaklı: (a) view of the east section of the landslide, (b) view of the west section of the landslide with a paleo-landslide and landslide ponds. 


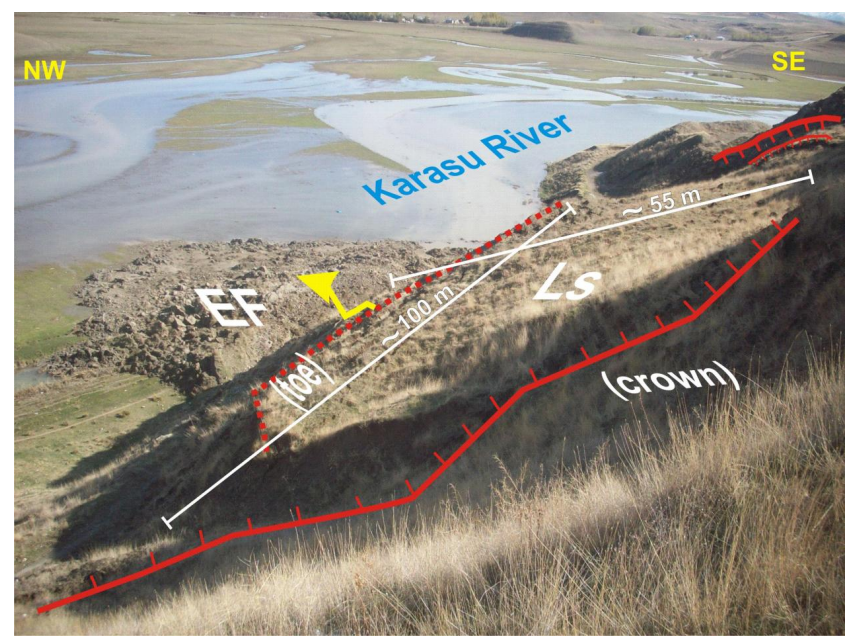

Fig. 8. A view from an earthflow and landslide that developed in Karasu Delta.
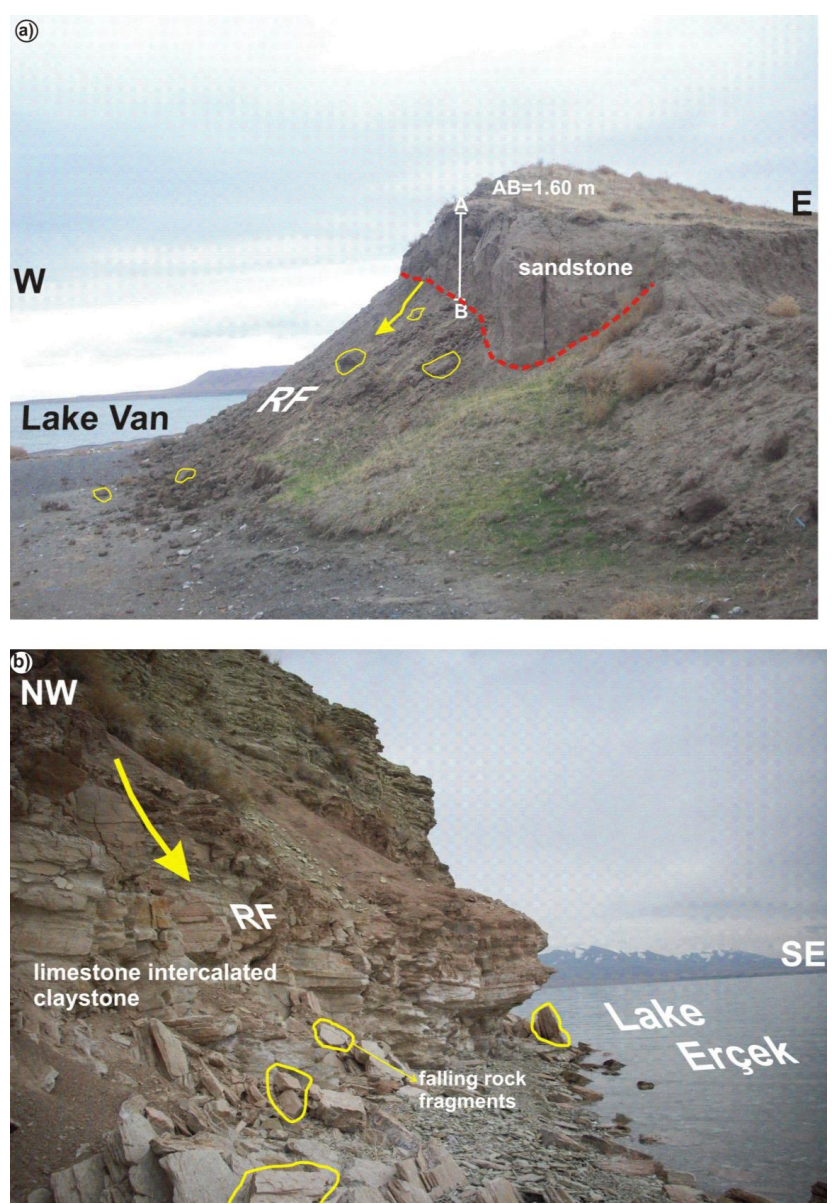

Fig. 9. (a) Rockfalls observed in a slope with sandstone lithology around Çitören village and (b) rockfalls observed in a slope with limestone-claystone lithologies at the western side of Lake Erçek. widespread liquefaction failures in the meizoseismal region. These ground failures were flow-type liquefaction, lateral spreading and ground settlement. Flow-type failures were observed frequently and were widespread in the field, in the form of sand cones and boils, and ejection of liquefied soils onto the surface through a ground crack (Fig. 10a). These features were mainly observed along the sides and in the floodplains of the streams and Lake Van shores. The grain size of the liquefied sediments that were seen on the surface varied from silt-sized grains to fine gravel (Fig. 10b and c). The liquefied deposits were mainly grey saturated sands (fine-coarse) mixed with silt and rare clay. Liquefactionrelated damage was very low when compared to the 1999 İzmit (Gölcük) earthquake, during which many buildings settled, tilted and were buried in the liquefied ground. The moment magnitude $\left(M_{\mathrm{w}}\right)$ of the İzmit (Gölcük) earthquake was 7.4, and the focal mechanism solution of the earthquake was an E-W right-lateral strike-slip fault. The maximum rightlateral offset was approximately $5 \mathrm{~m}$ on the surface (Barka et al., 2002). Contrary to this, the Van earthquake occurred on a blind thrust fault plane with $\mathrm{N} 70^{\circ} \mathrm{E}$ strike and NW dip (Doğan and Karakaş, 2013). The thrust offset created by the hanging wall overlapping the foot wall was approximately $3.5 \mathrm{~m}$ around the hypocenter (Irmak et al., 2012). The ground deformations were observed maximum $3 \mathrm{~km}$ south end of the surface rupture of the İzmit (Gölcük) earthquake, whereas the ground deformations were seen at most $50 \mathrm{~km}$ north and $20 \mathrm{~km}$ east of the surface rupture of the Van earthquake. The reason for that could be the rupturing of secondary intercontinental faults in the different locations of the compressional province during the earthquake (Doğan and Karakaş, 2013). In both basins, the groundwater levels are shallow $(1-2 \mathrm{~m})$ and the soil types are similar.

Although the magnitude of the Van earthquake was large enough and the Erciş Basin constitutes favorable soil liquefaction conditions, no liquefaction took place in the basin during the Van earthquake, whereas the Adapazarı Basin suffered extensive liquefaction and related damage during the 1999 İzmit (Gölcük) earthquake. Özvan et al. (2008) indicate that the liquefaction potential of the Erçis region is very high in a $M_{\mathrm{w}}=7.5$ earthquake and $0.35 \mathrm{~g}$ peak ground acceleration.

Lateral spreading is the movement of surficial soil layers or blocks in a direction parallel to the ground surface, and occurs when there is a loss of shear strength in a subsurface layer due to liquefaction (Rauch, 1997). The geologic conditions conducive to lateral spreading (gentle surface slope, shallow groundwater, liquefiable cohesionless soils) are frequently found along streams and other waterfronts in recent alluvial or deltaic deposits, as well as in loosely placed, saturated, sandy fills (Youd and Hoose, 1976). Horizontal displacements on a lateral spread can extend up to several meters with smaller associated settlements (Rauch and Martin, 2000). Lateral spreading failures were commonly observed and were widespread in the field from north of the Van city 
center to Erciş and its surroundings. Horizontal displacements ranged from a couple of meters $(1-2 \mathrm{~m})$ to several meters $(5-10 \mathrm{~m})$ with associated settlements from a couple of centimeters $(1-2 \mathrm{~cm})$ to several centimeters $(\max .50 \mathrm{~cm})$ in the field (Fig. 11a). A limited number of houses were only damaged due to lateral spreading in Çelebibağı, Erciş (Fig. 11b). Lateral spreading in one location was accompanied by landslide in Erçiş, Çelebibağı. Liquefied soil layers accompanied by low inclination in the topography $\left(3-5^{\circ}\right)$ and free face towards Lake Van caused lateral spreading in the Çelebibağılocation.

One of the effects of liquefaction was damage to the main water pipeline. The soil liquefaction and lateral spreading broke a section of the main water pipes installed to deliver water to Van Yüzüncü Yıl University main campus and some parts of the city of Van in Topaktass, located NW of the main campus (see Fig. 1). This resulted in the failure of water distribution to university campus and some parts of the city for a week. Ground settlements due to liquefaction were observed in several locations during the fieldwork, of which two are mentioned here as representative examples: in Çelebibağ 1 , Erçiş, where a house settled downward approximately $30 \mathrm{~cm}$ (Fig. 12a), and in Erçiş county center, some buildings and paved areas settled from $2 \mathrm{~cm}$ to $8 \mathrm{~cm}$ (Fig. 12b).

\subsection{Liquefaction analysis of soils according to PGAs}

Liquefaction analysis was performed by using estimated ground acceleration values from the attenuation relationships. This method developed by Dobry et al. (1981) is an empirical approach, and a pre-evaluation of soil liquefaction allows us to form a hypothesis when no subsurface soil and Standard Penetration Test (SPT) data are available. This approach utilizes threshold acceleration $\left(a_{\mathrm{t}}\right)$ and maximum ground acceleration $\left(a_{\max }\right)$ values and defines a safety factor that is greater than that required for the low liquefaction risk and less than that required for the high liquefaction risk. This method was employed for four sites where liquefaction was observed. The distances between the mid-center of each site and the epicenter were measured in GIS. These distances were used to calculate the maximum accelerations in each site by using the attenuation relationships of Ulusay et al. (2004) and Ambraseys et al. (2005). The factor of safety was considered to be 0.99 since the liquefaction took place in the specific locations. Since the safety factor and maximum acceleration values are known, the threshold acceleration values in each area were calculated according to Eq. (1). The calculated maximum acceleration and threshold acceleration values for each area are shown in Table 1.

$F=1.6 \times a_{\mathrm{t}} / a_{\max }$.

The threshold acceleration values that initiate the liquefaction in each site were calculated according to the approach established by Dobry et al. (1981). The $a_{\max }$ values calculated from the attenuation relationship of Ulusay et al. (2004)


Fig. 10. (a) Sand boils and ejection of liquefied soils into the surface through a ground crack in Karasu Delta, (b) sand cone of liquefied fine-grained soil in the eastern shores of Lake Van around Çitören village, and (c) sand boil of liquefied sand with gravels in the northern shores of Lake Van around south of Çelebibağı. 



Fig. 11. (a) Lateral spreading that developed around the shore of Karasu River in Karasu Delta and (b) lateral spreading that developed under a house in Çelebibağı, Erçiş.

were used in the calculations because their relationship fit well with the strong ground motion data recorded in far field of the Van earthquake. The threshold acceleration values obtained were approximately $267.70 \mathrm{~cm} \mathrm{~s}^{-2}(\sim 0.27 \mathrm{~g})$ for the 1st site, $340.24 \mathrm{~cm} \mathrm{~s}^{-2}(\sim 0.35 \mathrm{~g})$ for the 2nd site, $188.87 \mathrm{~cm} \mathrm{~s}^{-2}(\sim 0.19 \mathrm{~g})$ for the $3 \mathrm{rd}$ site, and $273.60 \mathrm{~cm} \mathrm{~s}^{-2}$ $(\sim 0.28 \mathrm{~g})$ for the 4 th site. The highest threshold acceleration value was noted in the 4th site, which was the closest of the four to the epicenter. The lowest threshold acceleration value was noted in the 3rd site, which was the farthest from the epicenter. As each of the four sites experienced liquefaction failures, the minimum threshold acceleration value for the initiation of soil liquefaction could be $188.87 \mathrm{~cm} \mathrm{~s}^{-2}$ $(\sim 0.19 g)$ in the earthquake region.

\subsection{Granulometric analysis of the liquefied soils}

Several soil samples were taken from the different localities of the earthquake region to define the relationship between
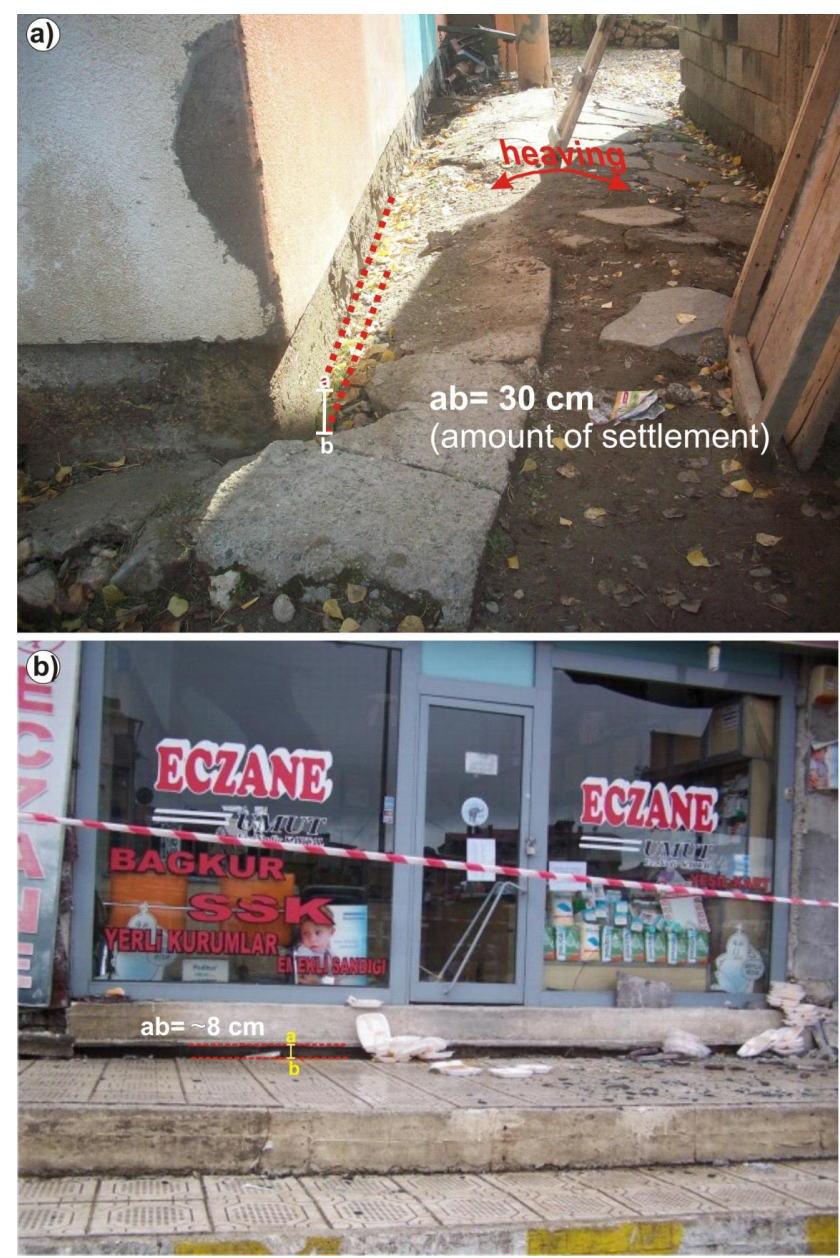

Fig. 12. (a) Liquefaction-related settlement that occurred under a house at Çelebibağı, Erçiş and (b) liquefaction-related settlement at the mid-part of the Erciş Basin (CGE, 2011).

liquefaction, grain size distribution and soil type. Twelve samples collected from the liquefied soils in different locations of the earthquake region were tested for grain size distribution (GSD) using sieve analyses. The purpose of the soil testing is to determine the grain size distribution and soil type of the liquefied soil layers and to compare the grain size distributions of the liquefied soil layers in the earthquake meizoseismal area. The laboratory results of the liquefied soils led to plotting grain size distribution curves, which enabled us to compare the laboratory results of liquefied soils in the Van earthquake and other earthquakes. With this, it is possible to compare the liquefied soils with the other soils that were liquefied in the previous earthquakes.

The GSD test presents silt and clay, sand and gravel ratios for a soil sample. The silt and clay ratio varied from $4 \%$ to $48.2 \%$, and the sand ratio varied from $48.9 \%$ to $96 \%$. The gravel ratio was very low and encountered only in two samples as $0.5 \%$ and $2.9 \%$. The majority of the liquefied soil samples (9 out of 12) were silty sand (SM) according 
Table 1. Estimated peak ground accelerations for the given distances and threshold acceleration values in each site.

\begin{tabular}{lrrr}
\hline $\begin{array}{l}\text { Distance to Epicenter } \\
(\mathrm{km})\end{array}$ & $\begin{array}{r}\text { Ulusay et al. (2004) } \\
\left(\mathrm{cm} \mathrm{s}^{-2}\right)\end{array}$ & $\begin{array}{r}\text { Ambraseys et al. (2005) } \\
\left(\mathrm{cm} \mathrm{s}^{-2}\right)\end{array}$ & $\begin{array}{r}\text { Threshold Acceleration Value } \\
\left(\mathrm{cm} \mathrm{s}^{-2}\right)\end{array}$ \\
\hline $16(1$ st Site $)$ & 432.6494 & 281.2873 & 267.7018 \\
5 (2nd Site) & 549.8952 & 464.8727 & 340.2477 \\
32 (3rd Site) & 305.2489 & 141.9205 & 188.8728 \\
15 (4th Site) & 442.1847 & 263.6486 & 273.6018 \\
\hline
\end{tabular}

to the Unified Soil Classification System (USCS). One sample was classified as clayey sand (SC) due to its plasticity index (10.3). Two samples were classified as poorly sorted sands (SP). Sand grains in the soil samples were mainly finemedium size. Only five samples had coarse-grained sand as up to $2 \%$ of the sand portion (S11). One sample (S5) was taken from the sliding soil mass located in the Karasu Delta along the eastern shores of Lake Van. This soil sample tested for GSD resulted in $13.4 \%$ silt+clay, $86.1 \%$ sand and $0.5 \%$ gravel, and was classified as silty sand $(\mathrm{SM}) . D_{60}(\mathrm{~mm})$ diameter sizes of the soil particles varied from $0.11 \mathrm{~mm}$ to $0.84 \mathrm{~mm}$ (Table 2). According to the GSD analyses of the liquefied soil samples, liquefied soils were mainly composed of fine-medium sized sand grains. Thus, the soil liquefaction is closely associated with the grain size. GSDs of ejected or boiled soils are placed between the high possibilities of liquefaction boundaries (Fig. 13). Sieve analysis results performed on sampled sand boils that occurred during the Van earthquake also indicated high potential for liquefaction (Çetin et al., 2011).

\section{Engineering geological assessment}

Four different sites were defined according to spatial occurrences of mass movements and liquefaction features. The first site is located around Çitören and Bardakçı, along the eastern shores of Lake Van. Landslides, earthflows, rockfalls, flow-type liquefaction, lateral spreading, and liquefactionrelated settlements were observed in this area. The PlioQuaternary units overlie the Pre-Neogene basement rocks in the areas close to the shores of Lake Van in this site. Landslides and earthflows took place on the slopes of loosely packed upper group Plio-Quaternary units deposited in the fluvial environment, and rockfalls occurred on the PlioQuaternary non-homogenous sandstone-claystone sequence, thus indicating a low energy environment of deposition (lacustrine). Liquefaction, lateral spreading and liquefactionrelated settlements occurred in loose, saturated alluvial units along the Karasu River and its floodplain. The laboratory results for the liquefied soil samples (S6, S7, S8, S9 and S10) yielded SM (more common), SC and SP type soils with $D_{60}$ varying from $0.12 \mathrm{~mm}$ to $0.39 \mathrm{~mm}$.

The second site is located in the south of Tabanli village. Surface features observed in the second site were flow-type liquefaction, lateral spreading and liquefaction-related settlements. These features occurred in loose, saturated alluvial units deposited in the floodplain of Karasu River and along the Karasu River and its tributaries. The laboratory result for the liquefied soil sample (S13) presented SM type soil with $0.11 \mathrm{~mm} D_{60}$.

The third site is located in the south of Erciş. Surface features observed in the third site were flow-type liquefaction, lateral spreading and liquefaction-related settlements. These features occurred in loose, saturated alluvial units deposited in the Erciş Basin, along the creeks located in the basin and on the north shores of Lake Van. The laboratory results for the liquefied soil samples (S1, S2, S3, S4, S11 and S12) yielded SM (more common) and SP type soils with $D_{60}$ varying from $0.19 \mathrm{~mm}$ to $0.84 \mathrm{~mm}$.

The fourth site is located in the north and south of Kozluca village and west of Lake Erçek. Landslides and rockfalls and flow-type liquefaction and lateral spreading were encountered in this area. Landslides occurred mainly in upper group Plio-Quaternary alluvial fan deposits, located south and north of Kozluca. Rockfall-type mass movements took place amongst basement rocks to the southwest of Kozluca and lower group Oligo-Miocene epiclastic sedimentary rocks in the western shores of Lake Erçek. Flow-type liquefaction and lateral spreading occurred in loose, saturated alluvial units deposited along Karasu River, in the northwest of Kozluca. Although no laboratory result exists for the fourth site, according to field observations the liquefied soils were similar to those liquefied in the other three sites.

A total of 19 slope failures were encountered in the field. The occurrence ratio of each mass movement was approximately $68 \%$ for the landslide, $16 \%$ for the earthflow, and $16 \%$ for the rockfall. A total of 30 liquefaction and liquefaction-related surface failures were encountered in the field. The occurrence ratios of each liquefaction and liquefaction-related surface failures were approximately $40 \%$ for the flow-type liquefaction, $40 \%$ for the lateral spreading, and $20 \%$ for the liquefaction-related settlement. Thus, the most common slope failure detected in the field was landslide, and the most common liquefaction and liquefaction-related surface failures encountered in the field were flow-type liquefaction and lateral spreading. When the slope failures and liquefaction features are evaluated together, the most common ground failures observed in 


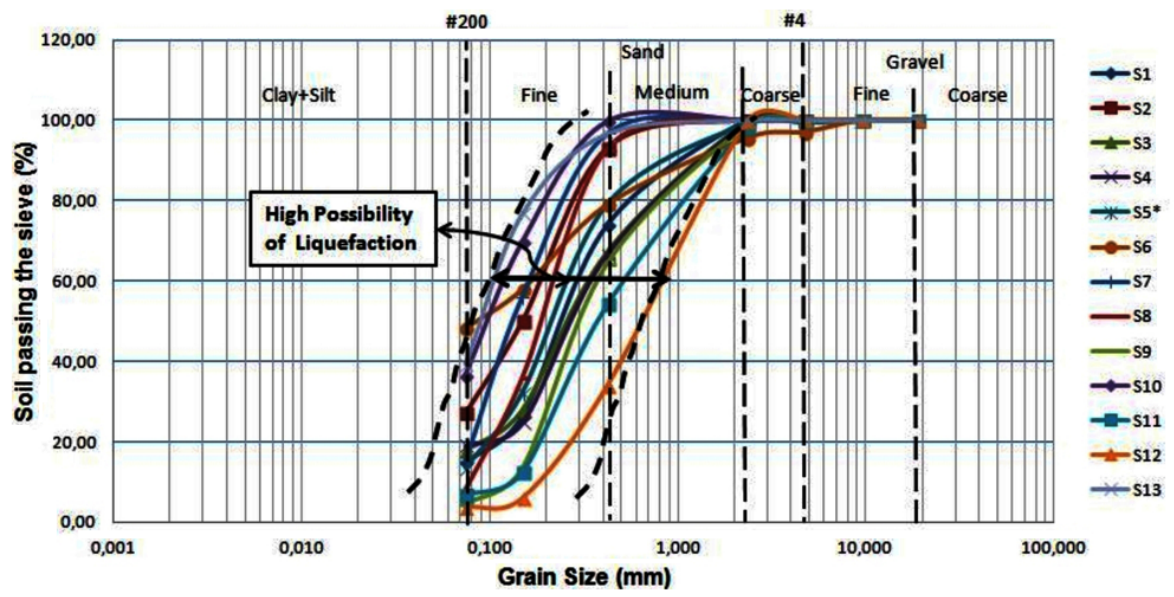

Fig. 13. Grain size distribution curves of liquefied soil samples.

Table 2. Grain size distribution test results for the liquefied 12 soil samples and 1 soil sample (S5*) taken from a landslide body.

\begin{tabular}{|c|c|c|c|c|c|c|c|}
\hline $\begin{array}{r}\text { Sample } \\
\text { No }\end{array}$ & Location & $\begin{array}{r}\text { Silt+Clay } \\
(\%)\end{array}$ & $\begin{array}{l}\text { Sand }(\%) \text {; } \\
\text { (Fine+Medium+Coarse) }\end{array}$ & $\begin{array}{r}\text { Gravel } \\
(\%)\end{array}$ & Description & USCS & $\begin{array}{r}D_{60} \\
(\mathrm{~mm})\end{array}$ \\
\hline S1 & Çelebibağı, Erçiş & 15 & $85(60+25+0)$ & 0 & Silty-Clayey Fine-Medium Sand & SM & 0.31 \\
\hline S2 & Çelebibağı, Erçiş & 27 & $73(66+7+0)$ & 0 & Silty-Clayey Fine-Medium Sand & SM & 0.19 \\
\hline S3 & Çelebibağı, Erçiş & 18 & $82(49+33+0)$ & 0 & Silty-Clayey Fine-Medium Sand & SM & 0.35 \\
\hline S4 & Çelebibağı, Erçiş & 19 & $80.5(48+32.25+0.25)$ & 0.5 & Silty-Clayey Fine-Medium Sand & SM & 0.36 \\
\hline $\mathrm{S} 5{ }^{*}$ & Eastern shores of Lake Van, around Karasu Delta & 13.4 & $86.1(65.9+20.1+0.1)$ & 0.5 & Silty-Clayey Fine-Medium Sand & SM & 0.28 \\
\hline S6 & Eastern shores of Lake Van, around Karasu Delta & 48.2 & $48.9(30.9+16.6+1.4)$ & 2.9 & Silty-Clayey Fine-Medium Sand & $\mathrm{SC}$ & 0.17 \\
\hline S7 & Eastern shores of Lake Van, around Karasu Delta & 15.1 & $84.9(81.5+3.4+0)$ & 0 & Silty-Clayey Fine-Medium Sand & SM & 0.17 \\
\hline S8 & Topaktaş & 8.3 & $91.7(84.6+7.1+0)$ & 0 & Silty-Clayey Fine-Medium Sand & SM & 0.23 \\
\hline S9 & Topaktaş & 4.6 & $95.4(60+34.25+1.15)$ & 0 & Silty-Clayey Fine-Medium Sand & SM & 0.39 \\
\hline S10 & Eastern shores of Lake Van, around Çitören & 37 & $63(60+3+0)$ & 0 & Silty-Clayey Fine-Medium Sand & SP & 0.12 \\
\hline S11 & Southeast of Çelebibă̆ğ, Erciş & 7 & $93(47+44+2)$ & 0 & Silty-Clayey Fine-Medium Sand & SM & 0.53 \\
\hline S12 & Southeast of Çelebibağı, Erciş & 4 & $96(30+66+0)$ & 0 & Silty-Clayey Fine-Medium Sand & SP & 0.84 \\
\hline $\mathrm{S} 13$ & Southwest of Tabanlı & 39.4 & $60.6(57.3+3.3+0)$ & 0 & Silty-Clayey Fine-Medium Sand & SM & 0.11 \\
\hline
\end{tabular}

$\mathrm{S}^{*}=$ Sample taken from a landslide.

the field were landslide, flow-type liquefaction, and lateral spreading. The maximum occurrence distance to the epicenter for the slope instabilities varied from $22 \mathrm{~km}$ to $23 \mathrm{~km}$, and the maximum occurrence distance to the epicenter for the liquefaction and liquefaction-related surface failures varied from $29 \mathrm{~km}$ to $31 \mathrm{~km}$ (Table 3). Thus, slope movements, liquefaction and liquefaction-related surface failures occurred within 20 to $30 \mathrm{~km}$ from the earthquake epicenter. Similar slope failures and liquefaction features that occurred in the Van earthquake have been presented in reconnaissance reports and proceedings papers (Çetin et al., 2011; Aydan et al., 2012; Ulusay et al., 2012).

\section{Conclusions and recommendations}

The 23 October 2011 Van earthquake severely affected humans, man-made structures, and nature. The human loss was 604 dead and countless injured, while the total number of moderately to severely damaged buildings was approximately 66550 . Additionally, 2900 buildings completely
Table 3. Occurrences and maximum distances to the earthquake epicenter of the mass movements and surficial features.

\begin{tabular}{lrr}
\hline $\begin{array}{l}\text { MM type and } \\
\text { Surficial Feature }\end{array}$ & Occurrence & $\begin{array}{r}\text { Max. Distance } \\
\text { to Epicenter }(\mathrm{km})\end{array}$ \\
\hline Landslide (Ls) & 13 & $\sim 22$ \\
Earthflow (EF) & 3 & $\sim 23$ \\
Rockfall (RF) & 3 & $\sim 23$ \\
Liquefaction (L) & 12 & $\sim 29$ \\
Lateral Spreading (LS) & 12 & $\sim 29$ \\
Settlements (S) & 6 & $\sim 31$ \\
\hline
\end{tabular}

collapsed (TRC, 2011). The impact on nature included surface ruptures, tensional ground cracks, slope instabilities, liquefaction and liquefaction-related failures. This study concentrated on the engineering geologic evaluation of the mass movements such as landslides, earthflows and rockfalls, liquefaction and surface features relating to liquefaction. Landslides occurred mainly on highly sloped young deposits, 
indicating that the slopes are not stable and an earthquake could trigger landslides. The main reasons for slope instabilities were strong earthquake shaking, an increase in pore water pressure due to the event occurring during a wet season, rugged morphology in high elevations (1650-2500 m), lithological properties and dips of the discontinuities. The geographic distribution of these landslides varied from the eastern shores of Lake Van and north of Kozluca, located to the east of Lake Erçek and to the south of Tabanlı village in the earthquake region. Rockfalls and earthflows were not observed as frequently as landslide-type movement. In general it has been observed that landslides and earthflows occurred on the slopes between $20^{\circ}$ and $45^{\circ}$ and consist of young Plio-Quaternary predominantly fine-grained deposits. Rockfalls occurred in the basement rocks, lower group OligoMiocene rocks and upper group Plio-Quaternary rocks. Liquefaction, lateral spreading and settlement-type surface features took place in loose and saturated alluvial deposits along Karasu River and its tributaries and floodplain. Seismically induced soil liquefaction and lateral spreading features were extensively observed, but liquefaction-related ground settlements were less frequently observed in the earthquake region. High groundwater level, loose sand type deposits (SM) with $D_{60}$ grain size varying from $0.11 \mathrm{~mm}$ to $0.84 \mathrm{~mm}$ and strong ground motion made possible widespread soil liquefaction. Sieve analysis results of the liquefied sand samples indicated high potential for liquefaction. However, property damage due to soil liquefaction was quite low considering the large magnitude of the main shock.

Ground failures were observed in the areas located within $20 \mathrm{~km}$ (2nd area) and $50 \mathrm{~km}$ (3rd area) north of the main thrust surface rupture. This indicates that secondary ground deformations developed extensively in the meizoseismal area of the earthquake. The hanging wall (northern block) of the thrust fault moved towards the footwall (southern block) so the impact of the earthquake was concentrated on the northern block. Slope instabilities, liquefaction and liquefactionrelated surface failures occurred within 20 or $30 \mathrm{~km}$ of the earthquake epicenter.

The relatively shallow epicenter $(5-20 \mathrm{~km})$, the wide area of the fault plane $(60 \times 20 \mathrm{~km})$ and the long duration of the rupturing $(50 \mathrm{~s})$ led to widely distributed slope instabilities and liquefaction, and associated deformations. These factors were effective in enhancing the structural damage. However, when we look at the ground accelerations (0.182$0.001 \mathrm{~g}$ ) recorded during the earthquake, it is obvious that these values are quite low considering the large magnitude of the earthquake $\left(M_{\mathrm{w}}=7.2\right)$. The damaged areas should have been affected by stronger ground motion than the places where the stations recorded strong ground motion. Attenuation relationships were used to estimate peak ground accelerations (PGAs), and an empirical liquefaction evaluation method employing ground accelerations was used to define the threshold accelerations initiating liquefaction. The minimum threshold acceleration value for the initiation of soil liquefaction was calculated to be $188.87 \mathrm{~cm} \mathrm{~s}^{-2}(\sim 0.19 \mathrm{~g})$ in the earthquake region. The attenuation of the strong ground motion in the earthquake region affected the intensity and depth of slope instabilities. The peak ground acceleration estimated from the attenuation relationship established by Ulusay et al. (2004) reaches $549.8952 \mathrm{~cm} \mathrm{~s}^{-2}(\sim 0.56 \mathrm{~g})$. Correspondingly, the majority of the mass movements took place in shallow depths. The variations in the depth of the slope instabilities are directly associated with the attenuation of the acceleration with the distance.

It is suggested that the earthquake-triggered landslides should be monitored, and the entire earthquake region should be studied in detail to reveal the mass movement and liquefaction distribution. A detailed engineering geologic and earthquake hazard evaluation should be performed before an engineering project is undertaken in the region. This event encourages civil protection measures that ensure minimal loss of human life and property damage. The GIS mapping of the geological impacts will be useful for the engineering evaluation and for the stakeholders. Slope stability analysis and liquefaction analysis within the capabilities of GIS should be performed to define potentially unstable slopes and liquefiable areas in the earthquake region. The slope movements and liquefaction failures that took place during the earthquake set a basis for construction of earthquake zoning maps and developing an earthquake database.

Acknowledgements. We would like to thank the Rector of Kocaeli University, Sezer Ş. Komsuoğlu, and the retired dean of the engineering faculty, Savaş Ayberk, and the Rector of Van 100. Y1l University, P. Peyami Battal for their support. We are grateful to Ioannis Kalogeras (reviewer) and the anonymous reviewer for their valuable comments. Also, a special thanks is extended to Ergin Ulutaş for his substantial contribution, Serdal Karaağaç for helping field and office work and John Pyle and Emily Brown Coolidge Toker for their reviewing effort.

Edited by: S. Tinti

Reviewed by: I. S. Kalogeras and one anonymous referee

\section{References}

Acarlar, M., Bilgin, Z. A., Erkal, T., Güner, E., Şen, A. M., Umut, M., Elibol, E., Gedik, İ., Hakyemez, Y., and Uğuz, M. F.: Geology of east and north of Lake Van, Mineral Research and Exploration (M.T.A) Report, No: 9469, 1991.

Aksoy, E.: Stratigraphy and tectonics of east and northeast of Van Province, Ph.D. thesis, Frrat University, Faculty of Sciences, Elazı $\breve{g}$, Turkey, 1988.

Akyol, N. and Karagöz, Ö.: Empirical attenuation relationships for western Anatolia, Turkey, Turkish J. Earth Sci., 18, 351-382, 2009.

Akyüz, S., Zabcı, C., and Sançar, T.: Preliminary report on the 23 October 2011 Van earthquake, available at: http://www.itu.edu. tr/DataFiles/Dosya/2011/van_rapor_ITU2.pdf (last access: 20 September 2012), 2011. 
Alberto, P. and Romeo, R.: Earthquake-induced ground failures in Italy, Eng. Geol., 58, 387-397, 2000.

Ambraseys, N. N., Douglas, J., Sarma, S. K., and Smit, P. M.: Equations for the estimation of strong ground motions from shallow crustal earthquakes using data from Europe and the Middle East: horizontal peak ground acceleration and spectral acceleration, Bull. Earthq. Eng., 3, 1-53, 2005.

Aydan, Ö., Ulusay, R., Kumsar, H., and Konagai, K.: Characteristics of 2011 Van earthquakes and some lessons learned, International Symposium on Earthquake Engineering, JAEE, 1, 27-36, 2012.

Aydar, E., Gourgaud, A., Ulusoy, İ., Digonnet, F., Labazuy, P., Şen, E., Bayhan, H., Kurttaş, Y., and Tolluoğlu, Ü.: Morphological analysis of active Mount Nemrut stratovolcano, eastern Turkey: evidences and possible impact areas of future eruption, J. Volcanol. Geotherm. Res., 123, 301-312, 2003.

Barka, A. A.: The north Anatolian fault zone, Ann. Tectonicae, 6, 164-195, 1992.

Barka, A., Akyüz, H. S., Altunel, E., Sunal, G., Çakir, Z., Dikbas, A., Yerli, B., Armijo, R., Meyer, B., de Chabalier, J. B., Rockwell, T., Dolan, J. R., Hartleb, R., Dawson, T., Christofferson, S., Tucker, A., Fumal, T., Langridge, R., Stenner, H., Lettis, W., Bachhuber, J., and Page. W.: The Surface Rupture and Slip Distribution of the 17 August 1999 İzmit Earthquake (M 7.4), North Anatolian Fault, B. Seismol. Soc. Am., 92, 43-60, 2002.

Bozkurt, E.: Neotectonics of Turkey-a synthesis, Geodinamica Acta, 14, 3-30, 2001.

Cetin, K. O., Turkoglu, M., Oral, S. Ü., and Nacar, U.: Van (Tabanl1) Earthquake $\left(\mathrm{M}_{w}=7.1\right)$ October 23, 2011 Preliminary Reconnaissance Report, Middle East Technical University, 31 pp., 2011.

CGE (Chamber of Geological Engineers): Report of Van (Tabanl1) and Edremit earthquakes, Chamber of Geological Engineers of Turkey, Ankara Main Office, 52 pp., 2011.

Chigira, M., Wu X., Inokuchi, T., and Wang, G.: Landslides induced by the 2008 Wenchuan earthquake, Sichuan, China, Geomorphology, 118, 225-238, 2010.

DEMP-ED (Disaster and Emergency Management PresidencyEarthquake Department): The 23 October 2011 Van earthquake report, 100 pp., 2011.

Dewey, J. F. and Burke, K. C. A.: Tibetan, Variscan and Precambrian basement reactivation: Products of continental collision, J. Geol., 81, 683-692, 1973.

Dobry, R., Stokoe, K. H., Ladd, R. S., and Youd, T. L.: Liquefaction susceptibility from S-wave velocity, ASCE National Convention, St. Louis, Missouri, 26-31 October, 81-544, 1981.

Doğan, B. and Karakaş, A.: Geometry of co-seismic surface ruptures and tectonic meaning of the 23 October $2011 \mathrm{Mw} 7.1$ Van earthquake (East Anatolian Region, Turkey), J. Struct. Geol., 46, 99-114, 2013.

Doğan, B., Karakaş, A., and Karaağaç, S.: Preliminary report of October 23, 2011 Van earthquake, Kocaeli University, Geological Engineering Dept., 11 pp., 2011 (in Turkish).

EERI (Earthquake Engineering Research Institute): Learning from Earthquakes: The Mw 7.1 Erciş-Van, Turkey Earthquake of October 23, 2011, Special Earthquake Report, 17 pp., 2012.

Emre, Ö., Duman, T. Y., Özalp, S., and Elmacı, H.: Field Observations and Preliminary Evaluations of the Source Fault of the 23 October 2011 Van earthquake, General Directorate of Mineral Research and Exploration, Active Tectonic Research Unit, avail- able at: http://www.mta.gov.tr/v2.0/deprem/2011_Van-Depremi_ On-Degerlendirmeler.pdf (last access: 22 September 2012), 2011.

GEER (Geotechnical Extreme Events Reconnaissance): Geotechnical Reconnaissance of the 2011 Christchurch, New Zealand Earthquake, Report No. GEER-027, edited by: Cubrinovski, M., Green, R. A., and Wotherspoon, L., available at: http://www. geerassociation.org/ (last access: 14 September 2012), 2011.

Gülkan, P. and Kalkan, E.: Attenuation modeling of recent earthquakes in Turkey, J. Seismol., 6, 397-409, 2002.

Güner, Y.: Geology, geomorphology and evolution of the Nemrut volcano, Geomorphology J., 12, 23-65, 1984 (in Turkish with English Abstract).

Hempton, M. R.: Constraints on Arabian plate motion and extensional history of the Red sea, Tectonics, 6, 687-705, 1987.

Irmak, T. S., Doğan, B., and Karakaş, A.: Source mechanism of the 23 October 2011 Van (Turkey) earthquake $(\mathrm{Mw}=7.1)$ and aftershocks with its tectonic implications, Earth Planet. Space, 64, 1-13, 2012.

JSCE (Japan Society of Civil Engineers): Kocaeli (Turkey) Earthquake, 17 August 1999, Mw 7.4, available at: http:// www.jsce-int.org/disaster_report/kocaeli_e.htm (last access: 12 September 2012), 2000.

Kausar, A., Petley, D., and Sadiq, S.: Surface deformation and mass movements caused by the 2005 Kashmir earthquake, northern Pakistan, in: Proceedings International Symposium in Pacific Rim, INTERPRAEVENT 2010 Symposium, Taipei, Taiwan, edited by: Chen, S.-C., International Research Society, 323-332 pp., 2010.

Keefer, D. K.: Landslides caused by earthquakes, Geol. Soc. Am. Bull., 95, 406-421, 1984.

Keefer, D. K., Wartman, J., Ochoa, C. N., Rodriguez-Marek, A., and Wieczorek, G. F.: Landslides caused by the M 7.6 Tecoman, Mexico earthquake of January 21, 2003, Eng. Geol., 86, 183197, 2006.

Ketin, İ.: Kurzer Bericht über die letzten Erdbeben in der Türkei, Geol. Rundsch., 35, 36-38, 1948.

Koçyiğit, A.: Neotectonics and seismicity of East Anatolian, Workshop-2002 on the Geology of East Anatolian, Van, Turkey, 2002.

KOERI (Kandilli Observatory and Earthquake Research Institute): 23 October 2011 Van Earthquake (Mw 7.2) Evaluation Report, National Earthquake Monitoring Centre, available at: http: //www.koeri.boun.edu.tr2011 (last access: 16 September 2012), 2011.

Köse, O., Gökdere, F., and Tolluoğlu, D.: General overview of the Lake Van Basin, 12th Proceedings of National Clay Symposium, 23-26, 2005 (in Turkish).

METU-EERC (Middle East Technical University-Earthquake Engineering Research Center): Field observations of seismic and structural damage of 23 October $2011 \mathrm{Mw} 7.2$ Van earthquake, Report No: METU/EERC 2011-04, 2011.

Miyagi, T., Higaki, D., Yagi, H., Doshida, S., Chiba, N., Umemura, J., and Satoh, G.: A reconnaissance report on landslide disasters in northeast Japan following the $M 9$ Tohoku earthquake, Landslides, 8, 339-342, 2011.

MRE (Mineral Research and Exploration): 1/500000 scale geology maps of Turkey, Van-K50 Plate, General Directorate of Mineral Research and Exploration, Ankara-Turkey, 2002. 
Özbey, C., Saria, A., Manuela, L., Erdik, M., and Fahjan, Y.: An empirical attenuation relationship for Northwestern Turkey ground motion using a random effects approach, Soil Dyn. Earthq. Eng., 24, 115-125, 2004.

Özkaymak, Ç.: Active tectonic features of Van City and near surroundings, M.Sc. thesis Yüzüncü Y1l University, Faculty of Sciences, Van, Turkey, 76 pp., 2003.

Özvan, A., Şengül, M. A., and Tapan, M.: On the geotechnical properties of Neogene sediments of the Lake Van Basin in the vicinity of Erciş, Geosound, 52, 297-310, 2008.

Parlak, O., Delaloye, M., Kozlu, H., Höck, V., and Çelik, Ö. F.: Geochemistry and tectonic setting of the Yüksekova ophiolite from the south-east Anatolian orogenic belt, International Earth Sciences Colloquium on the Aegean Region (IESCA-2000), 25-29 September, 240 pp., 2000.

Rajendran, K., Rajendran, C. P., Thakkar, M. and Tuttle, M. P.: The 2001 Kutch (Bhuj) earthquake: Coseismic surface features and their significance, Current Sci., 80, 11, 1397-1405, 2001.

Rauch, A. F. and Martin, J. R.: EPOLLS Model for predicting average displacements on lateral spreads, J. Geotech. Geoenviron. Eng., 126, 360-371, 2000.

Rauch, A. F.: EPOLLS: An empirical method for predicting surface displacements due to liquefaction-induced lateral spreading in earthquakes, Ph.D. thesis, Virginia Polytechnic Institute and State Univ., Blacksburg, Va, 333 pp., 1997.

Saglam, A.: Stratigraphy, paleontology and deposition environments of Van formation outcropped in east and southeast of Lake Van, M.Sc. thesis, Yüzüncü Y1l University, Faculty of Sciences, Van, Turkey, 88 pp., 2003.

Şaroğlu, F. and Yılmaz, Y.: Geological evolution and basin models during Neotectonic episode in the eastern Anatolia, B. Mineral Res. Explor., 107, 61-83, 1986.

Şaroğlu, F., Emre, Ö., and Kuşçu, İ.: Active Fault Map of Turkey (1/2000000 scale), General Directorate of Mineral Research and Exploration, Ankara-Turkey, 1992.

Şengör, A. M. C. and Kidd, W. S. F.: Post-collisional tectonics of the Turkish Iranian Plateau and a comparison with Tibet, Tectonophysics, 55, 361-376, 1979.

Şengör, A. M. C. and Y1lmaz, Y.: Tethyan evolution of Turkey: A plate tectonic approach, Tectonophysics, 75, 181-241, 1981.

Şengör, A. M. C., Görür, N., and Şaroğlu, F.: Strike-Slip faulting and related basin formation in zones of tectonic escape, strikeslip deformation, basin formation and sedimentation, Society of Economic Paleontologists and Mineralogists, Spec. Publ., 37, 227-264, 1985.

Şengör, A. M. C., Özeren, M. S., Keskin, M., Sakınç, M., Özbakır, A. D., and Kayan, İ.: Eastern Turkish high plateau as a small Turkic-type orogen: Implications for post-collisional crustforming processes in Turkic-type orogens, Earth-Sci. Rev., 90, 1-48, 2008.

Toker, M.: Neotectonic elements controlling the micro-earthquake potential of Van segment, ATAG10-Active Tectonics Research Group (ATAG) 10th Meeting Abstracts, p. 91, İzmir, 2006.

TRB (Transportation Research Board): Landslides: Investigation and Mitigation, edited by: Turner, A. K. and Schuster, R. L., National Research Council (US), Special Report 247, 673 pp., 1996.
TRC (Turkish Red Crescent) Van Earthquake Humanitarian Aid Operation, Operations Update-14 Report, available at: http:// reliefweb.int/node/457669, last access: 22 August 2012.

TSMS (Turkish State Meteorological Service): available at: http: //www.mgm.gov.tr/, last access: 22 January 2013.

Ulusay, R., Tuncay, E., Sönmez, H., Gökçeoğlu, C.: An attenuation relationship based on Turkish strong motion data and isoacceleration map of Turkey, Eng. Geol., 74, 265-291, 2004.

Ulusay, R., Kumsar, H., Konagai, K., and Aydan, Ö.: The characteristics of geotechnical damage by the 2011 Van-Erciş earthquake, in: Proceedings of the International Symposium on Engineering Lessons Learned from the 2011 Great East Japan Earthquake, Tokyo, Japan, 1-4 March 2012, 1926-1936, 2012.

Ulutaş, E. and Özer, M. F.: Empirical attenuation relationship of peak ground acceleration for Eastern Marmara region in Turkey, Arab. J. Sci. Eng., 35, 187-203, 2010.

Ulutaş, E., Coruk, Ö., and Karakaş, A.: A study of residuals for strong ground motions in AdapazarıBasin, NW Turkey, by Ground Motion Predictions Equation (GMPEs), Studia Geophysica et Geodaetica, 55, 213-240, 2011.

USGS instrumental intensity map of the 23 October 2011 Van earthquake, available at: http://earthquake.usgs.gov/earthquakes/ shakemap/global/shake/b0006bqc/, last access: 12 September 2012.

Varnes, D. J.: Slope movement types and processes, Special Report 176, in: , Landslides: Analysis and Control, edited by: Schuster, R. L. and Krizek, R. J., TRB, National Research Council, Washington, DC, 11-33, 1978.

Wang, W., Wu, H.-L., Nakamura, H., Wu, S.-C., Ouyang, S., and Yu, M.-F.: Mass movements caused by recent tectonic activity: The 1999 Chi-chi earthquake in central Taiwan, Island Arc, 12, 325-334, 2003.

Wasowski, J. and Gaudio, V. D.: Evaluating seismically induced mass movement hazard in Caramanico Terme (Italy), Eng. Geol., 58, 291-311, 2000.

Yilmaz, Y.: Comparison of young volcanic associations of western and eastern Anatolia formed under a compressional regime: A review, J. Volcanol. Geotherm. Res., 44, 69-87, 1990.

Yılmaz, Y., Dilek, Y., and Işık, H.: Geology of Gevaş (Van) Ophiolite and a syn-kinematic shear zone, B. Turkish Geol. Assoc., 24, 37-44, 1981.

Yılmaz, Y., Yiğitbaş, E., and Genç, Ş. C.: Ophiolitic and metamorphic assemblages of southeast Anatolia and their significance in the geological evolution of the orogenic belt, Tectonics, 12-5, 1280-1297, 1993.

Youd, T. L. and Hoose, S. N.: Liquefaction during 1906 San Francisco earthquake, Journal of the Geotechnical Engineering Division, Am. Soc. Civil Eng., 102, 425-439, 1976.

YTU-NSRC (Yıldız Technical University-Natural Sciences Research Center): Geological and geomorphical preliminary evaluation report of October 23, 2011 Van Earthquake (Mw 7.2), Yıldiz Technical University Natural Sciences Research Center, 2011.

Zaruba, Q. and Mencl, V.: Landslides and Their Control, Elsevier Scientific Pub. Co., 324 pp., 1982. 